نقش حفاظتى بايوجار در رطوبتهاى مختلف خاك براى جلوگيرى از هدررفت خاك در شرايط آزمايشخاهى

\author{
نبيه كريمى، ليلا غلامى" و عطاله كاويان'

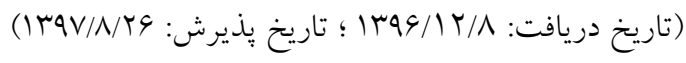

جكيده

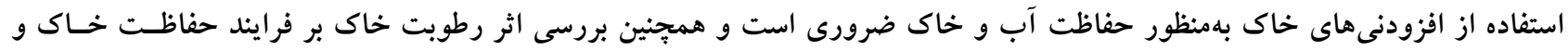

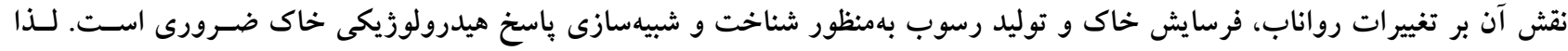

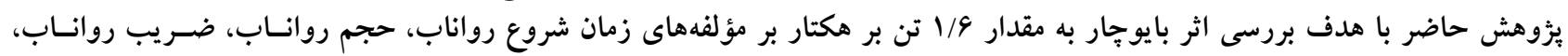

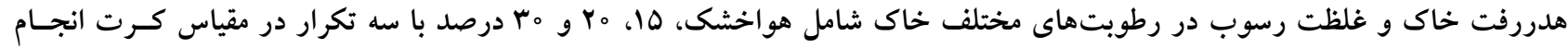

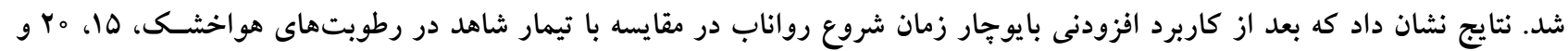

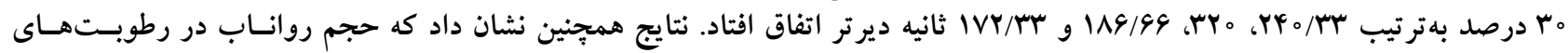

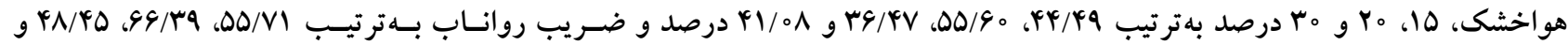

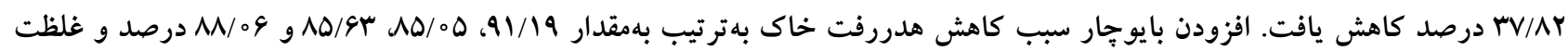

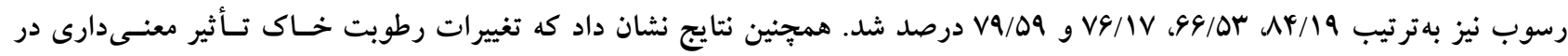

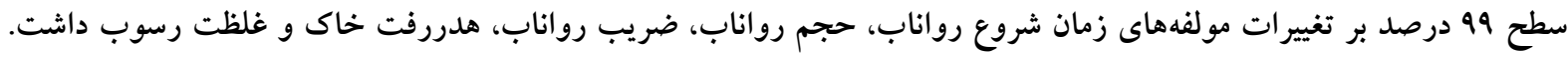

وازههاى كليدى: افزودنى آلى خاك، رطوبت بيشين خاك، فرسايش خاك، كرت آزمايشكاهى

1. كروه مهندسى آبخيزدارى، دانشكده منابع طبيعى، دانشگاه علوم كشاورزى و منابع طبيعى سارى، سارى، ايران

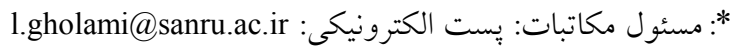


در برابر فرسايش خاك نشان داد كه مقدار فرسايش خاك ارتباط مقدمه

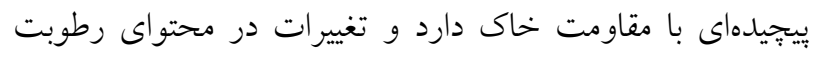

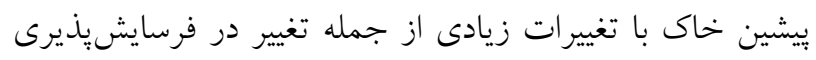

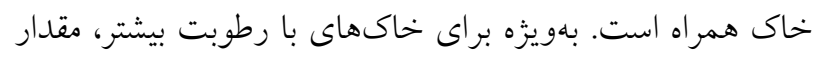

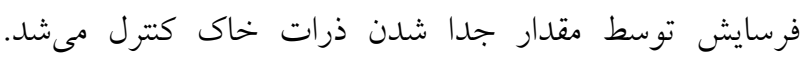
همجنين اثرات رطوبت خاك در توليد رواناب و رسوب مى تونداند

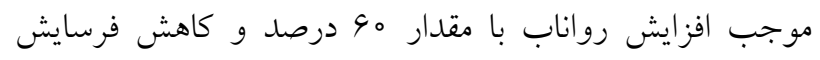

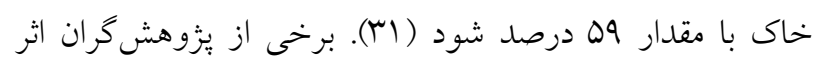

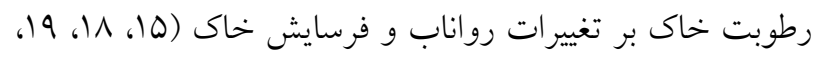

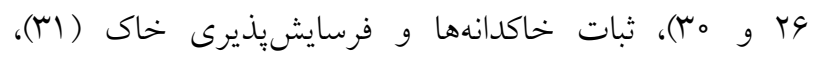

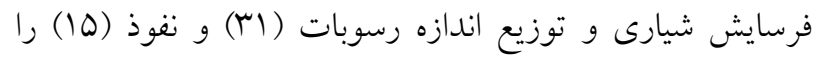

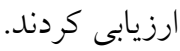
از طرفى بررسى و بيشبينى رفتار يكى سامانه آبخيز بر اساس

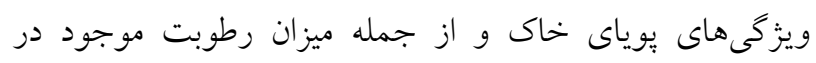

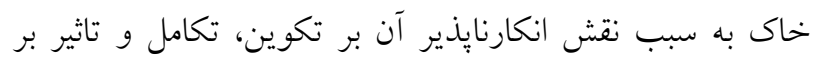
بسيارى از فرايندهاى مهم از قبيل ايجاد رواناب بسيار حائز

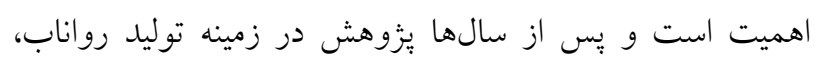

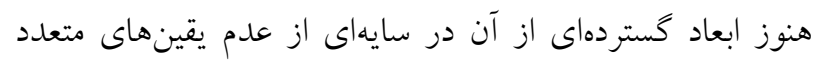

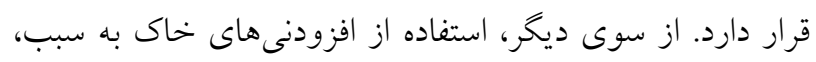

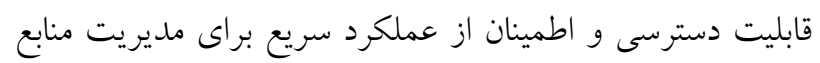

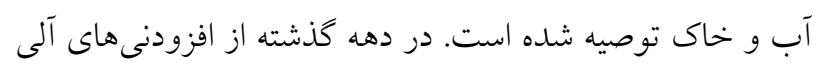

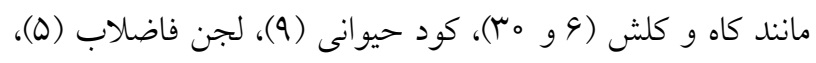

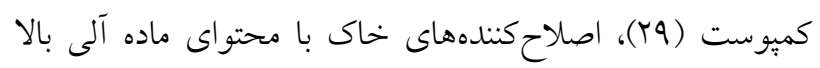

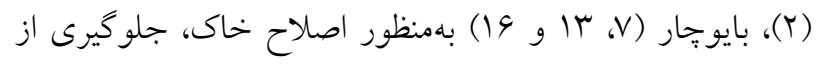

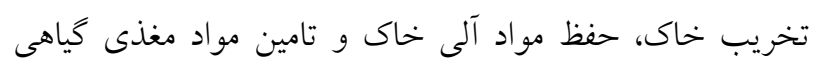
استفاده شده است. بايوجار ماده غنى شدهاى است كه از تجزيه

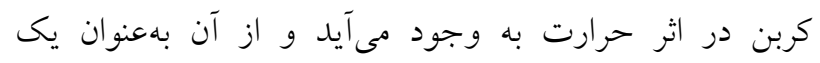
افزودنىهاى خاك براى بهبود و حفظ حاصلخيزى خاك و نيز

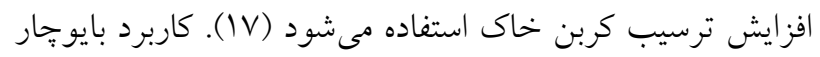

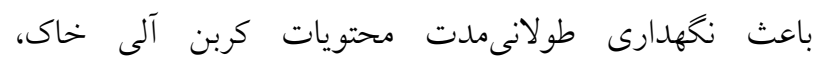
حاصلخيزى خاك، تهويه خاك، بهبود بارورى، افزايش راندمان مواد مغذى و به حداكثر رساندن بهرهورى از محصولات زراعى از اوايل دهه م191 يُزوهشخران بهطور جدى تأثيرات عوامل مختلف مؤثر بر فرايند فرسايش را بررسى كردهاند و نتايج

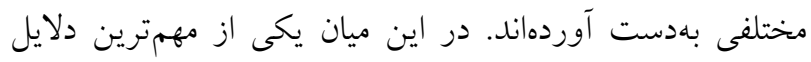

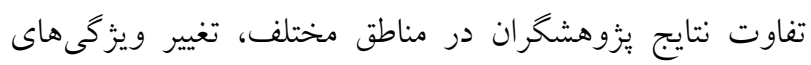

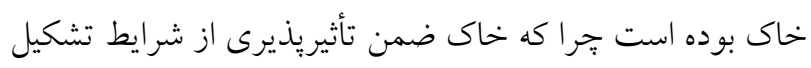

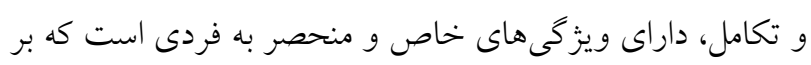

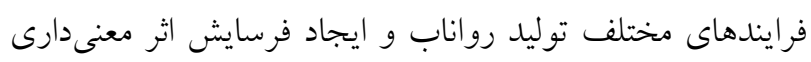

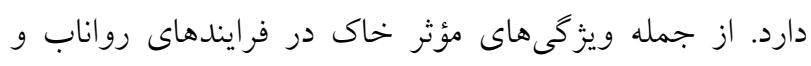

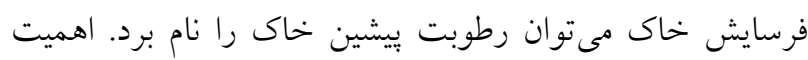

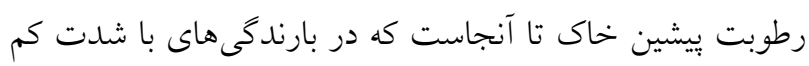

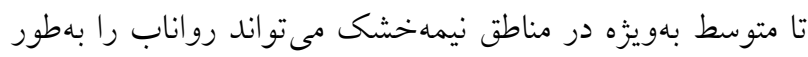

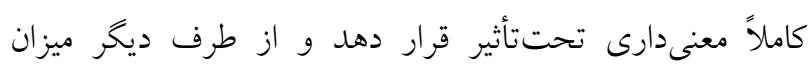

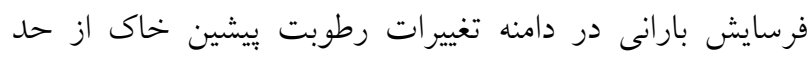

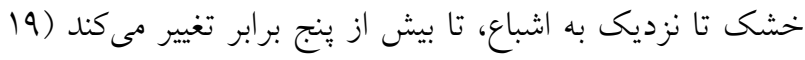

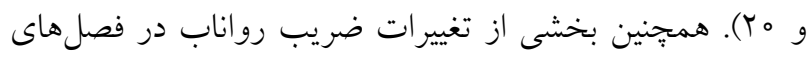

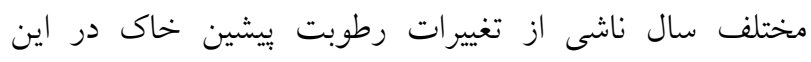

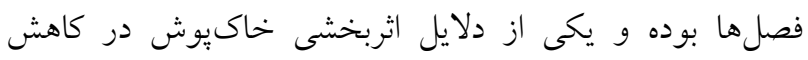

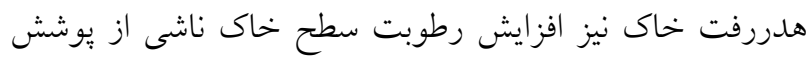

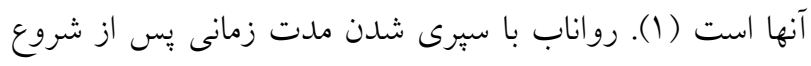

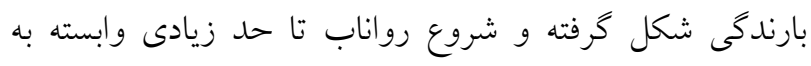

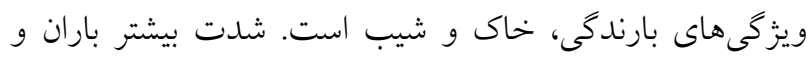

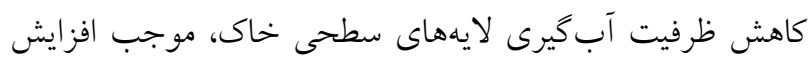

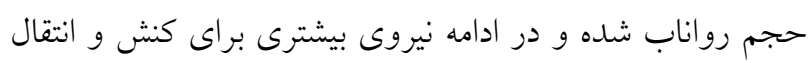

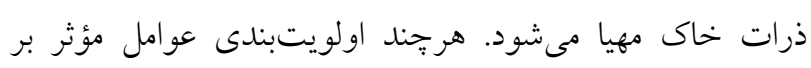
زمان شروع رواناب و ضريب رواناب تا حد زيادى به مقياس هريس

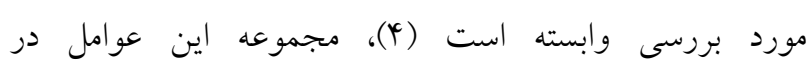

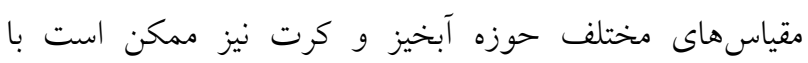

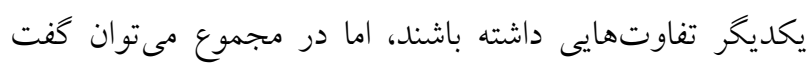

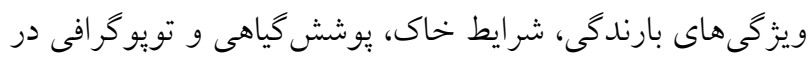

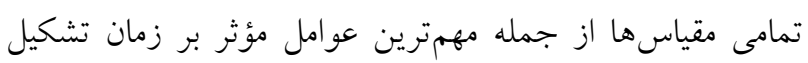

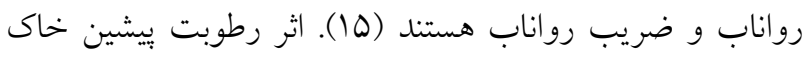


خشك شده (شكل 1- الف) و در مرحله بعدى بقاياى سنگ و

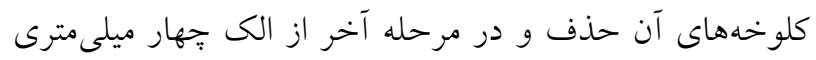

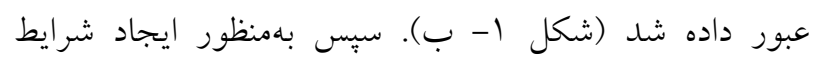

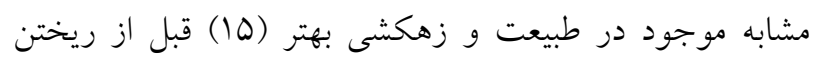

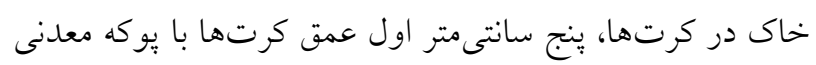

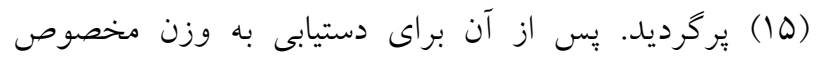

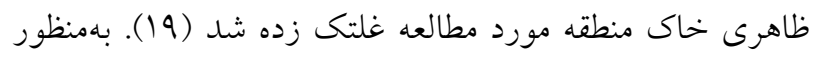

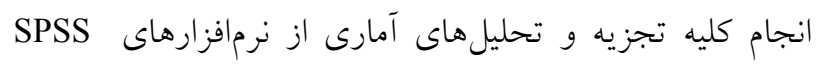
Excel (Ver.rr)

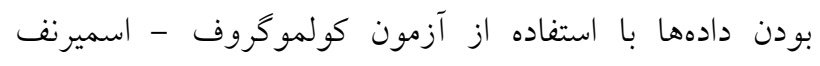
بررسى شد و مقايسه يارامترهاى مورد بررسى قبل و بعد از ازدول

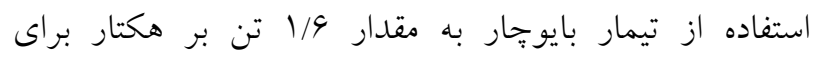

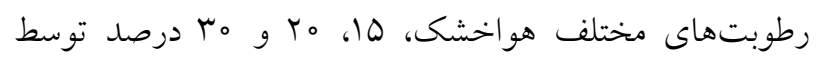

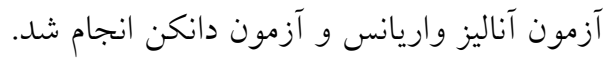

\section{تهيه و آمادهسازى بايوجار}

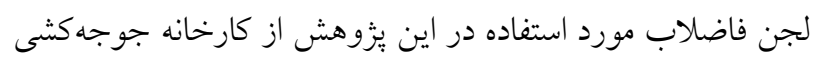

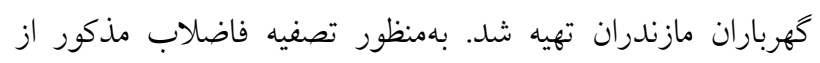
روشهاى بيولوزيكى تصفيه فاضلاب صنعتى به روش هوازى و

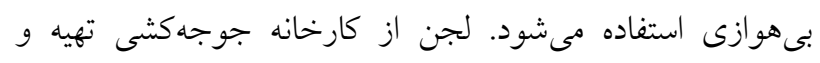

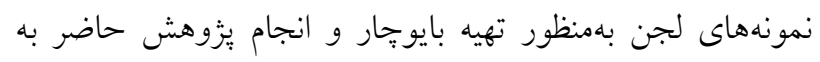

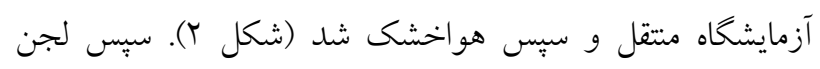
هواخشك شده در شرايط فاقد اكسيزن درون كوره تهيه بايوجار

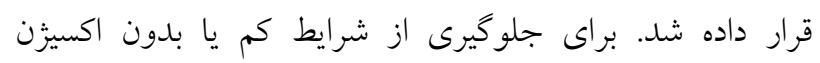

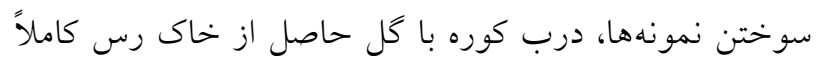

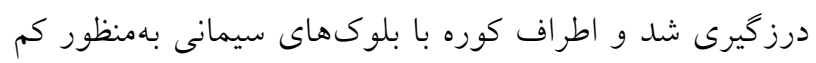

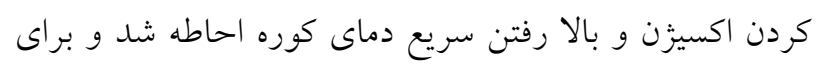

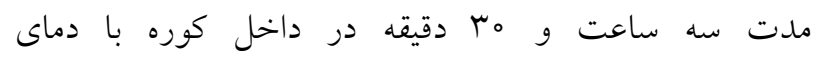

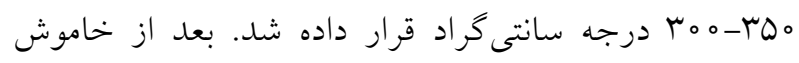

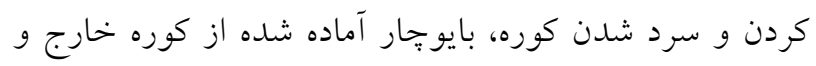

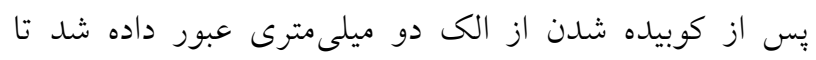

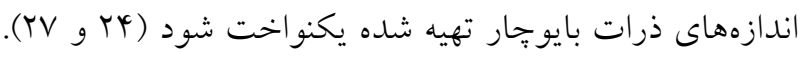

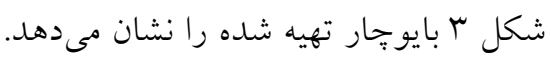

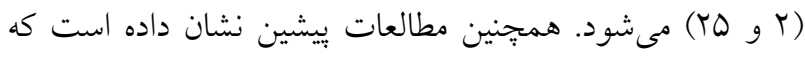

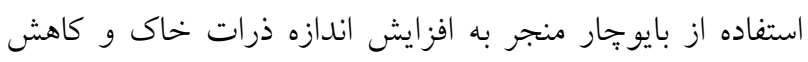

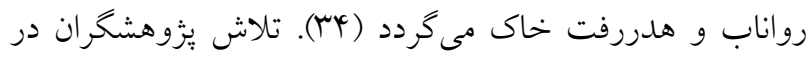

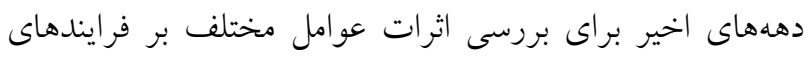

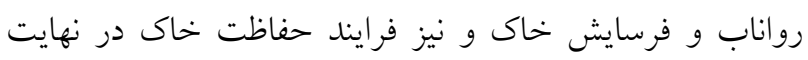
منجر به استفاده از سامانهاى شبيهسازى باران، رواناب و و ونسي فرسايش و رسوب شده است تا حدى كه امروزه شبيهسازى باران بهعنوان روشى استاندارد براى واسنجى و اعتبارسنجى مدلهاى

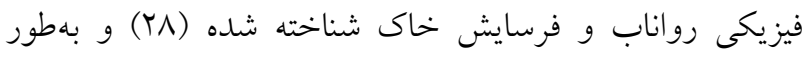

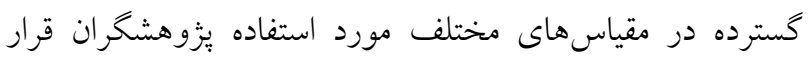
كرفته است. شبيهساز باران نقش مهمى در درى فرايندهاى حفاظت خاك داثته و توليد رواناب و فرسايش خاك را كنترل كرده است و قابليت تكرار را فراهم مى كند.

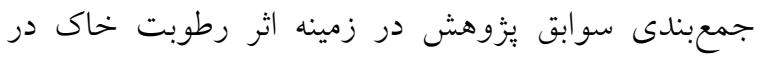
فرايند حفاظت خاك نشان داد كه تاكنون اثر رطوبتهاى

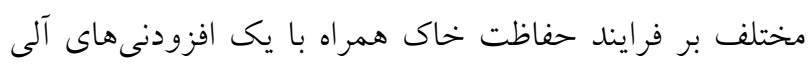

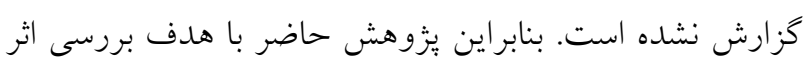

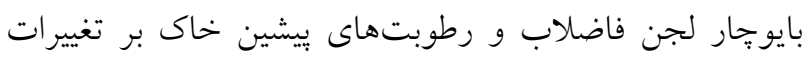
مؤلفههاى رواناب، هدررفت خاك و غلظت رسوب درب در مقياس

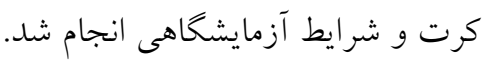

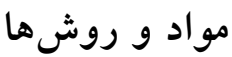

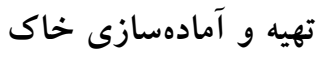
آزمايشهاى مربوط به بخش جمع آورى رواناب و رسوب و نيز

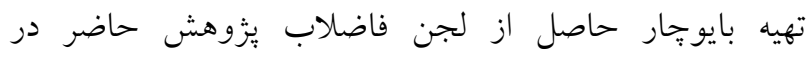

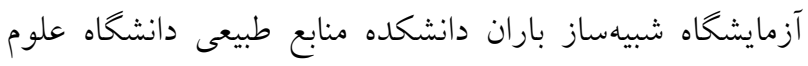
كشاورزى و منابع طبيعى سارى انجام شد. همجينين خاك از باز

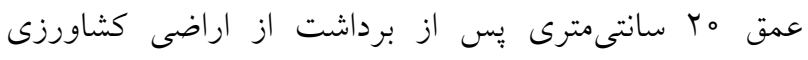

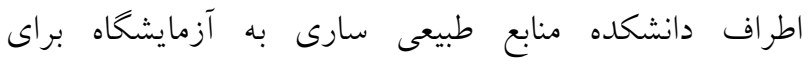
آمادهسازى و انجام آزمايشهاى اوليه روى آن انتقال داده شد.

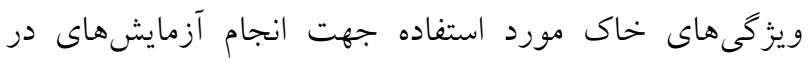
جدول (1) ارائه شده است. براى آمادهسازى خاى، ابتدا هوا 
نشريه علوم آب و خاك (علوم و فنون كشاورزى و منابع طبيعى) / سال بيست و سه / شماره سوم / باييز ^هـا

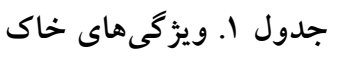

\begin{tabular}{|c|c|c|c|c|c|c|c|c|}
\hline \multirow{2}{*}{$\begin{array}{c}\text { EC } \\
\text { (دسىزيمنس بر متر) }\end{array}$} & \multirow{2}{*}{$\mathrm{pH}$} & آهك & مواد آلى & كربن آلى & سيلت & رس & شن & \multirow{2}{*}{ بافت خاك ـ } \\
\hline & & & & (درصد) & & & & \\
\hline$\circ / \wedge \vee \wedge$ & $V \pi V$ & $\pi / T \Delta$ & $1 / 91$ & $0 / 91$ & Tr/r & $1 \pi / 9$ & $\Delta r / \Lambda$ & لومى شنى \\
\hline
\end{tabular}

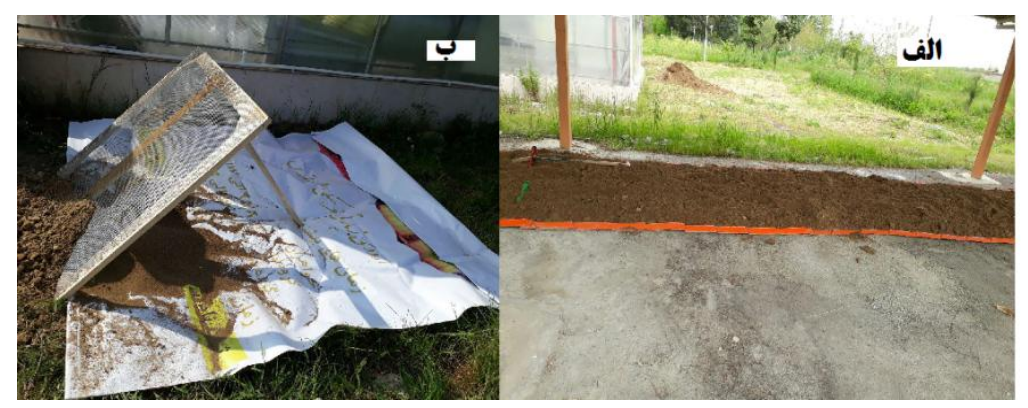

شكل ا. مراحل آماده سازى خاك براى انجام يزوهش حاضر: الف) خشى كردن خاك در هواى آزاد و ب) الى كردن

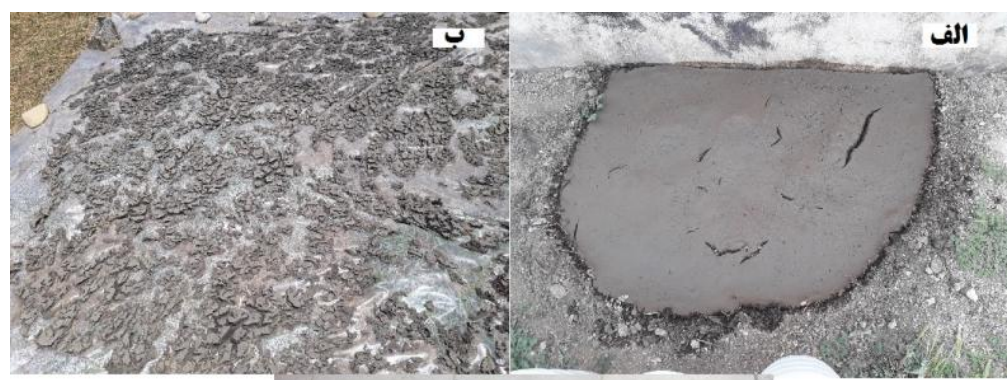

?

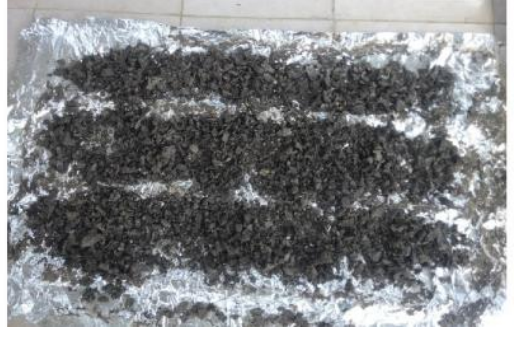

شكل r. مراحل خشك كردن لجن فاضلاب: الف) قراردادن در جاله بهنظور كاهش حجم آب اضافى موجود در لجن،

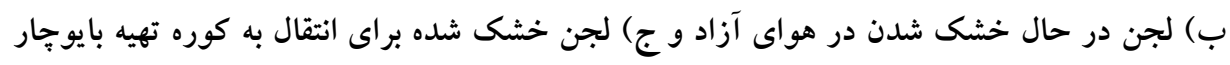

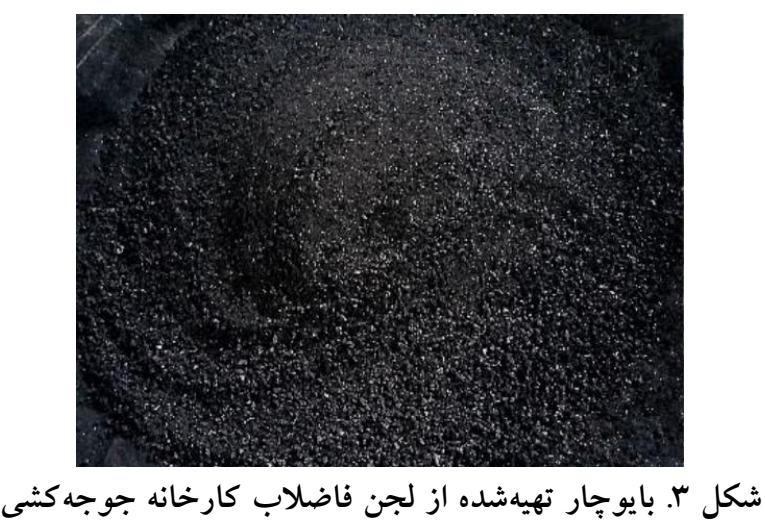


ميلى متر در طول سال، فصـل هـاى خشـى و مرطسوب خـاك

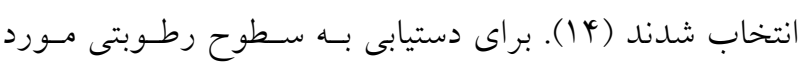

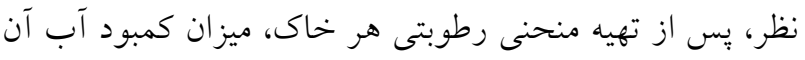

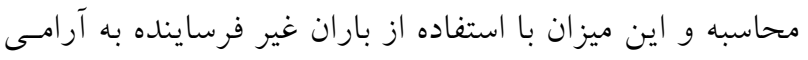
و به نحوى كه روانابى ايجاد نشود، به خاك اضافه شد (4 (1).

مولفههاى رواناب و هدررفت خاك و آزمونهاى آمارى بس از ثبت زمان شروع رواناب، بـهــــت ما دقيقـه نمونسهــاى رواناب و رسوب با فاصله زمانى دو دقيقهاى و بــا سـه تكــرار در ظرفهاى نمونهبردارى جمع آورى شد (YV). بِ از اتمـام مــدت

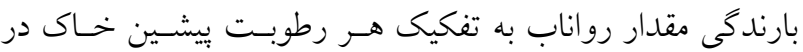

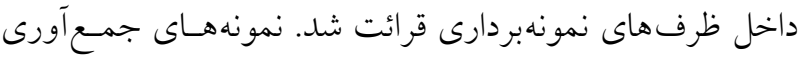

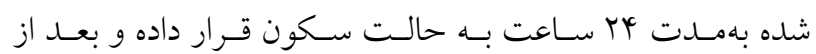

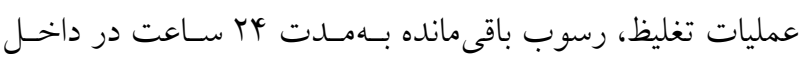
آون در دماى هـ ا درجه سانتى گراد قرار كرفنتد. در نهايت مقدار

هدررفت خاك با استفاده از ترازو توزين شد (ك، با و و (YV).

\section{نتايج و بحث}

دادههاى مقادير ميانگين، انحراف معيار و ضريب تغييرات زمـان

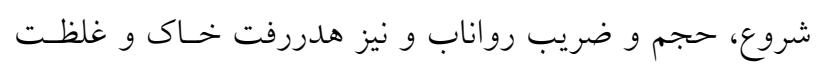

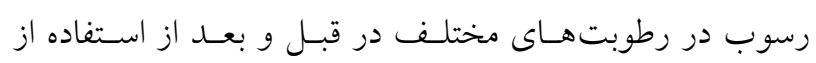

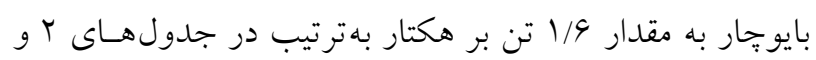

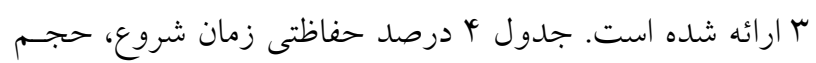
و ضريب رواناب، هدررفت خـاك و غلظـت رسـوب بايوجـار نسبتت به تيمار شاهل در رطوبتهـاى مختلـف خهاك را نشـان

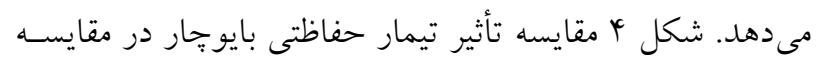

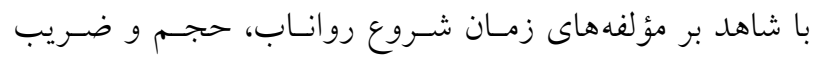

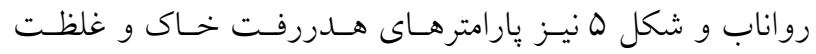
رسوب در رطوبتهاى مختلف خاك را نشان مىدهد. جدول ه ه

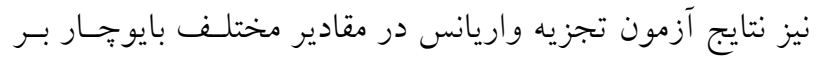

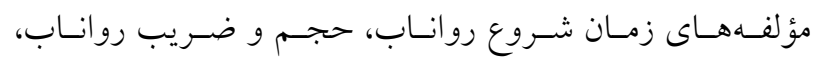
هدررفت خاك و غلظت رسوب را نشان مىدهد.
شبيه

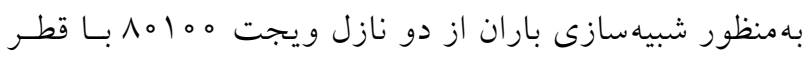

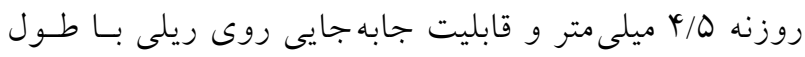

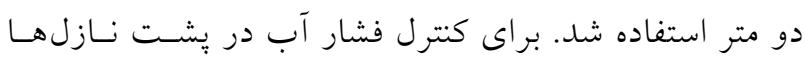

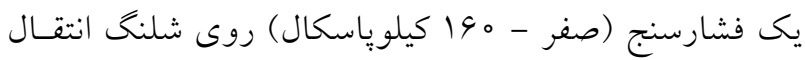
آب نصب شده است. به منظور راهاندازى شبيهسـاز و كنتـرل

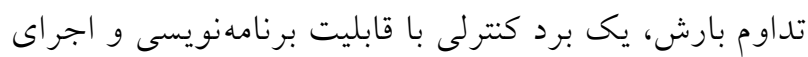

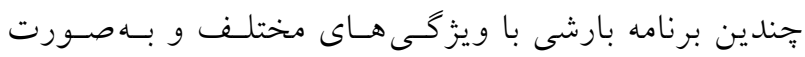

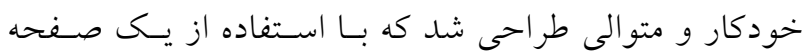

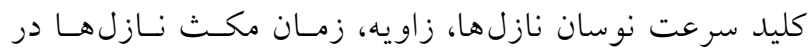

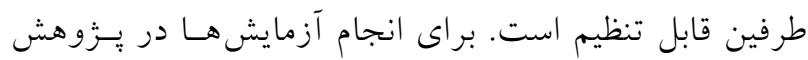

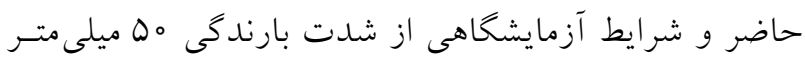

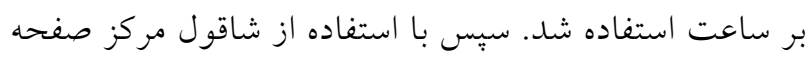

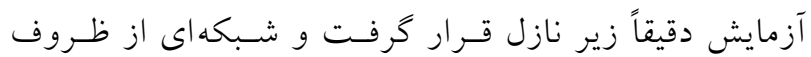

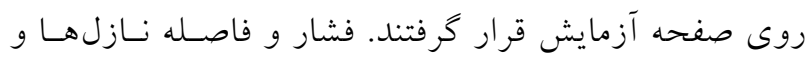

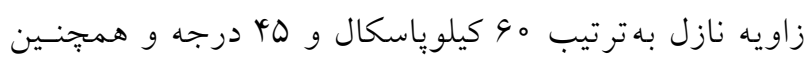

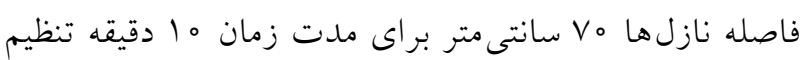

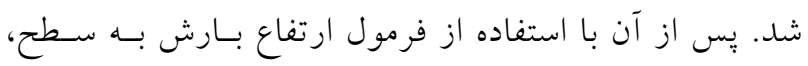

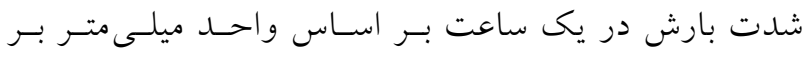
ساعت محاسبه شد (رابطه ()). $\mathrm{I}=\frac{\mathrm{Q}}{(\mathrm{A} \times \mathrm{t})} \times \mathrm{r}_{0} 。$

كه در آن ا شدت باران به ميلسىمتـر بـر سـاعت،Q ارتفـاع آب

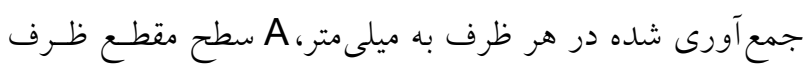
به سانتىمتر مربع و t زمان به دقيقه است.

\section{انتخاب سطح رطوبت بيشين خاك}

از آنجايى كه رطوبت ييشين خاك در دقيقهاى اوليسه يـس از

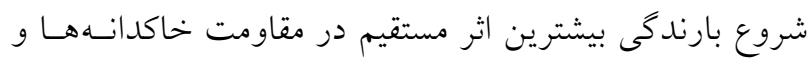

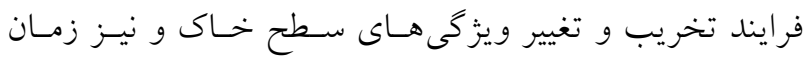
تشكيل رواناب دارد (N). لذا جهار سطح رطوبتى شامل سطوح

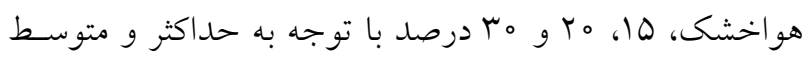

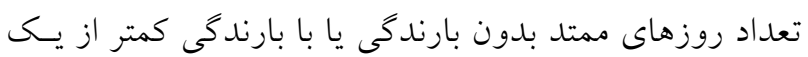


جدول r. مقادير ميانگين، انحر اف معيار و ضريب تغييرات زمان شروع رواناب، حجم و ضريب رواناب در رطوبت مختلف استفاده شده با

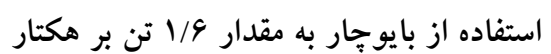

\begin{tabular}{|c|c|c|c|c|c|c|c|}
\hline \multicolumn{3}{|c|}{ تيمار بعد از استفاده از بايو :حار } & \multicolumn{3}{|c|}{ تيمار فاقد بايو جار } & \multirow[b]{2}{*}{ 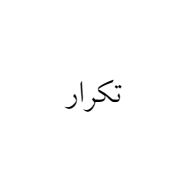 } & \multirow{2}{*}{ ردوبت } \\
\hline ضريب رواناب & حجم رواناب & زمان شروع رواناب & ضريب رواناب & حجم رواناب & زمان شروع رواناب & & \\
\hline Tr/M & $1 / 90$ & $900 / \pi \mu$ & $\Delta r / Q T$ & $r / 01$ & r9o & ميانخين & S \\
\hline $0 / 94$ & $0 / 09$ & $r q / 0 r$ & YNG & $\circ / \Lambda$ & $\Delta r / 91$ & انحراف معيار & 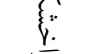 \\
\hline$\% / 04$ & O/OH & $\% / 04$ & $\circ / 09$ & $\circ / 0 \Delta$ & $0 / 10$ & ضريب تغييرات & $\xi$ \\
\hline$T V / F T$ & $Y / 0 Y^{4}$ & kar/m & $\Lambda 1 / 0 \Lambda$ & $4 / 09$ & IVT/N & ميانخين & \\
\hline$\circ / \Delta 0$ & $0 / 0 \psi^{4}$ & $r / \wedge q$ & $4 / 99$ & $0 / 49$ & $Y N / D Q$ & انحراف معيار & 10 \\
\hline 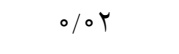 & $0 / 0 Y$ & $\circ / 0 \circ \Delta$ & $0 / 09$ & $\circ / 10$ & $0 / Y \Lambda$ & ضريب تغييرات & \\
\hline $49 / 40$ & $T / N Q$ & $r \circ V / \mu$ & $19 / 94$ & $Y N I$ & IYT/GV & ميانخين & \\
\hline $0 / 9 V$ & $0 / T V$ & GY/DT & $0 / 09$ & $\circ / Y_{0}$ & $\Delta \Delta / 01$ & انحراف معيار & ro \\
\hline$\circ / 14$ & $0 / 09$ & $\circ / Y_{0}$ & $0 / 09$ & $\circ / \wedge$ & $\circ / 4 Q$ & ضريب تغييرات & \\
\hline $09 / V 9$ & $r / T Y$ & Too/ & $99 / 10$ & $\Delta / \Delta \circ$ & rᄉ & ميانخين & \\
\hline $9 / 1 \pi$ & $0 / M Y$ & re/4V & $\circ / \Delta r$ & $0 / \mu 1$ & $9 / 94$ & انحراف معيار & r。 \\
\hline $0 / 10$ & $\circ / 10$ & ०/NY & $\circ / \circ \circ \Delta$ & $0 / 09$ & $O / M Y$ & ضريب تغييرات & \\
\hline
\end{tabular}

جدول r. مقادير ميانخين، انحر اف معيار و ضريب تغييرات هدررفت خاك و غلظت رسوب در رطوبت مختلف استفاده شده با استفاده از

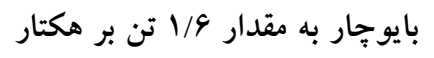

\begin{tabular}{|c|c|c|c|c|c|}
\hline \multicolumn{2}{|c|}{ تيمار بعد از استفاده از بايو هار } & \multicolumn{2}{|c|}{ تيمار فاقد بايو:جار } & \multirow{3}{*}{ 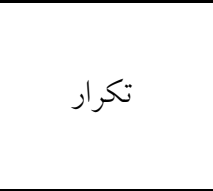 } & \multirow{3}{*}{ رطوبت (درصد) } \\
\hline غلظت رسوب & هدرفت خاك & غلظت رسوب & هدررفت خاك & & \\
\hline (كرم بر ليتر) & (كرم) & (كرم بر ليتر) & (كرم) & & \\
\hline $\mid r / 94$ & $T Q / \mu r$ & $\wedge 1 / 9 \circ$ & $r \wedge V / 9 \Lambda$ & ميانكين & \\
\hline$r / 90$ & $\Delta / V_{0}$ & $\circ / v r$ & $\mid r / r_{0}$ & انحر اف معيار & 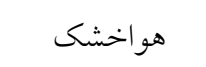 \\
\hline$\circ / r_{0}$ & $0 / 4 T$ & $\circ \% \circ \wedge$ &.$/ 04$ & ضريب تغييرات & \\
\hline $11 / N{ }^{4}$ & $Y Y / 00$ & $r o / .9$ & $190 / 0 r$ & ميانخين & \\
\hline $1 / \pi v$ & $r / \mu r$ & $\mu / \mu_{0}$ & $10 / 01$ & انحر اف معيار & 10 \\
\hline.$/ 11$ & $\circ / 4$ & .109 & $0 / 09$ & ضريب تغييرات & \\
\hline ir/ly & rV/rT & $Q Q / 1 Q$ & $r 09 / \wedge 9$ & ميانخين & \\
\hline $1 / r_{0}$ & $r / 99$ & $1 / 94$ & $r \Delta / V_{0}$ & انحر اف معيار & ro \\
\hline $0 / 091$ & $\circ / V$ & $\circ \% \mu r$ & $\circ / 10$ & ضريب تغييرات & \\
\hline 19/vi & $94 / 90$ & $99 / 90^{\circ}$ & QMT/TV & ميانخين & \\
\hline$\mu / r_{0}$ & $V / 44$ & $r / \Lambda Y$ & r4/94 & انحر اف معيار & r。 \\
\hline $0 / 19$ & $\circ / 11$ & $\circ / r^{2}$ & $\% \circ \mathrm{V}$ & ضريب تغييرات & \\
\hline
\end{tabular}


جدول \&. درصد حفاظتى زمان شروع، حجم و ضريب رواناب، هدررفت خاك و غلظت رسوب بايوجار با مقدار 1/9 تن بر هكتار در رطوبت هاى مختلف خاك

\begin{tabular}{|c|c|c|c|c|c|}
\hline غلظت رسوب & هدررفت خاك & ضريب رواناب & حجم رواناب & زمان شروع رواناب & \\
\hline $14 / 19$ & $91 / 19$ & $r \Lambda / \circ Y^{r}$ & $k y / k q$ & $99 / \mathrm{V} 9$ & هواخشك \\
\hline $99 / 0 T^{2}$ & $\Lambda \Delta / \circ \Delta$ & $99 / 49$ & $\Delta \Delta / 9 \circ$ & INF/GY & 10 \\
\hline $\mathrm{VG/IV}$ & $\Lambda Q / G Y$ & $\forall \wedge / \uparrow Q$ & $M G / 4 V$ & $10 \circ / D Y$ & ro \\
\hline$\vee Q / 0 q$ & $M / \circ \varphi$ & rV/AY & $41 / 0 \wedge$ & $G \mid 0 / 4 V$ & r。 \\
\hline
\end{tabular}

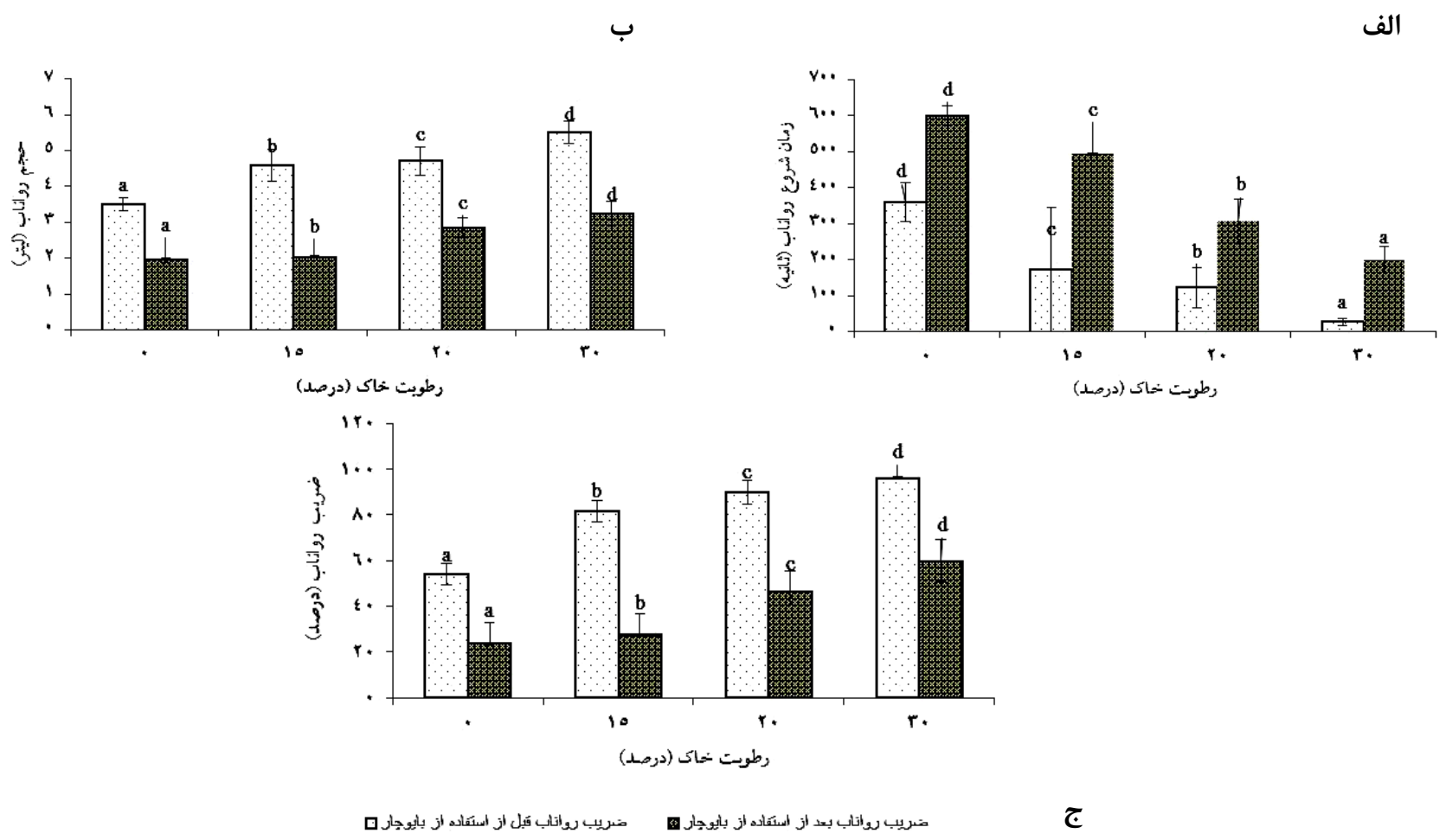

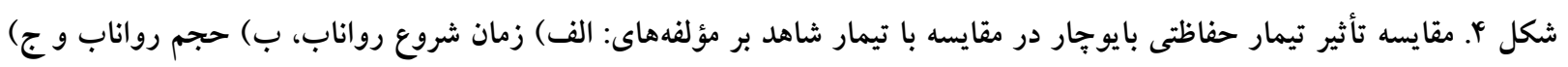

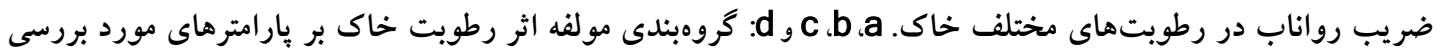

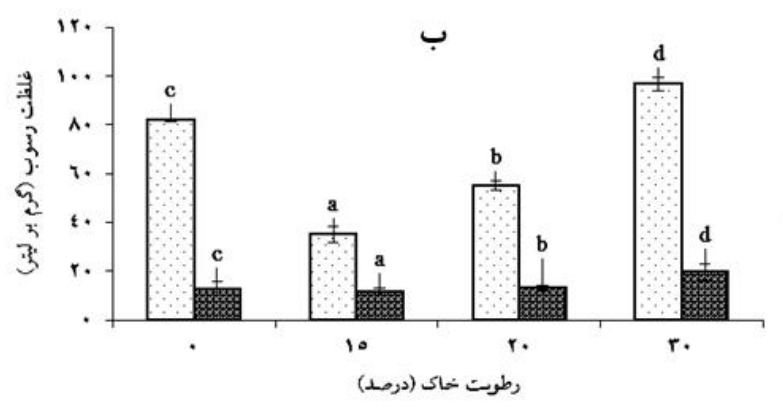

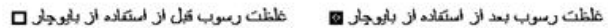

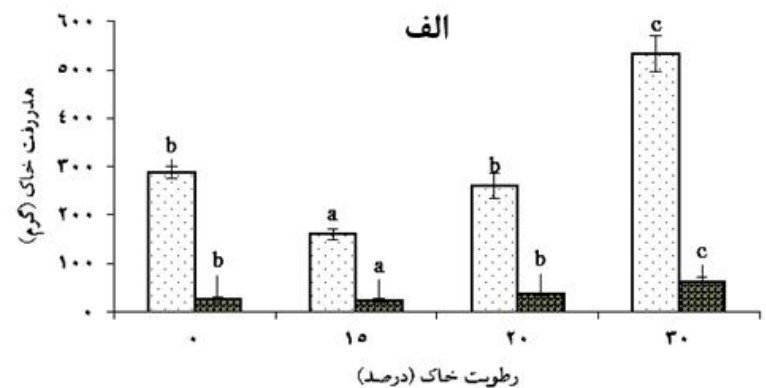

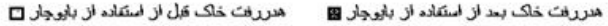

شكل ه. مقايسه تأثير تيمار حفاظتى بايوجار در مقايسه با تيمار شاهد بر مؤلفهاى: الف) هدررفت خاك و ب) غلظت رسوب

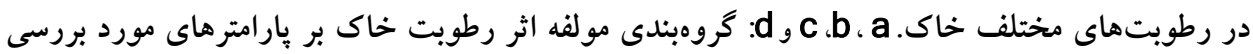


جدول ه. نتايج آزمون تجزيه واريانس در مقادير مختلف بايوجار بر مؤلفهاى زمان شروع رواناب، حجم و ضريب رواناب، هدررفت خاك

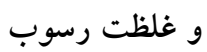

\begin{tabular}{|c|c|c|c|c|c|c|}
\hline سطح معنىدارى & 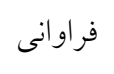 & ميانگين مربعات & درجه آزادى & مجموع مربعات & منابع تغييرات & مؤلفههاى مورد بررسى \\
\hline$\%$ & $9 \pi / 19$ & $\begin{array}{l}\text { QVTQN/०。 } \\
\text { IOKr/ON }\end{array}$ & $\begin{array}{l}r \\
\wedge \\
11\end{array}$ & $\begin{array}{l}r q \mid \wedge 9 Y / 00 \\
|r| \Lambda N / 99 \\
r O Y \circ \Lambda Y / 99\end{array}$ & درون دروهى كروهى & زمان شروع رواناب \\
\hline$\% \% \circ$ & TY/TY & $\begin{array}{l}1 / 11 \\
0 / 049\end{array}$ & $\begin{array}{l}r \\
\wedge \\
11\end{array}$ & $\begin{array}{l}r / \Delta D \\
\circ / r q r \\
r / 90\end{array}$ & درون بروهى كروهى & حجم رواناب \\
\hline $0 / 001$ & $T N / T Y$ & $\begin{array}{l}\text { NYN/GQ } \\
r \circ / 04\end{array}$ & $\begin{array}{l}r \\
\wedge \\
11\end{array}$ & $\begin{array}{l}\text { TQYG/OV } \\
\text { TYO/MV } \\
\text { TVMG/4Y }\end{array}$ & درون كروهى كروهى & ضريب رواناب \\
\hline$\%$ & rV/Qr & $\begin{array}{l}\text { I. } 1 Y / O Y \\
Y V / 0 Y\end{array}$ & $\begin{array}{l}r \\
\wedge \\
11\end{array}$ & $\begin{array}{l}\text { rorr/OA } \\
\text { rIG/IV } \\
\text { rroq/VQ }\end{array}$ & دين كروهى & هدررفت خاك \\
\hline$\% \circ$ & $\mathrm{V} / \mathrm{VA}$ & $\begin{array}{l}r 9 / 99 \\
0 / 09\end{array}$ & $\begin{array}{l}r \\
\wedge \\
11\end{array}$ & $\begin{array}{l}11 N / 91 \\
r \circ / V V \\
109 / V 0\end{array}$ & درون كروهى كروهى & غلظت رسوب \\
\hline
\end{tabular}

شروع رواناب در رطوبتهاى مختلف خاك در سطح 99 درصد

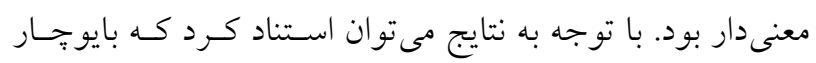

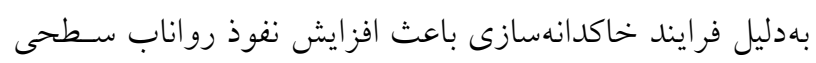

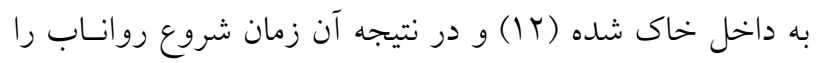

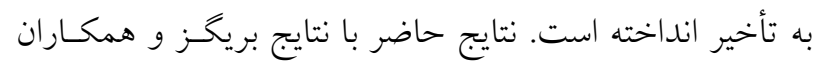

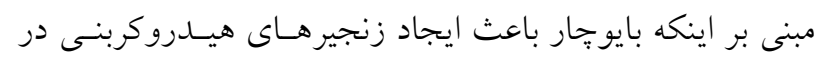

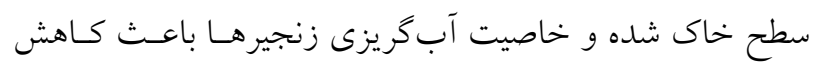

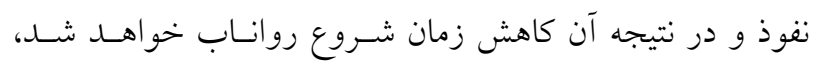

$$
\text { مغايرت داشت (r). }
$$

مقادير حجم رواناب قبل از استفاده از بايو جار در رطوبـتهــاى

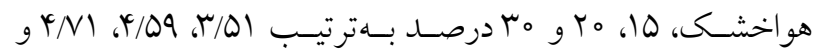

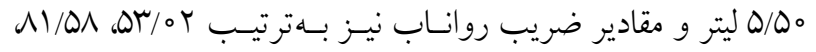

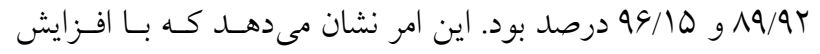
سطوح رطوبتى مقادير حجم رواناب و ضريب رواناب نيـز افزايش
نتايج ارائه شده در جدول r نشان مى دهد كه مقادير زمان شروع

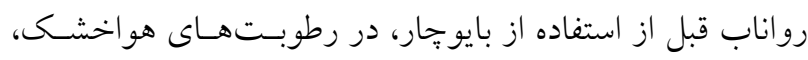
10

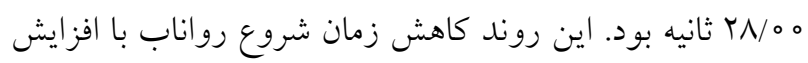

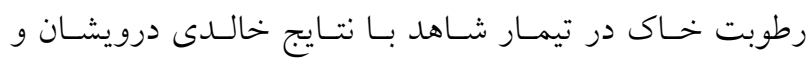
همكاران، مبنى بر رابطـهـ معكسوس و معنسى دار رطوبـت ييشـين

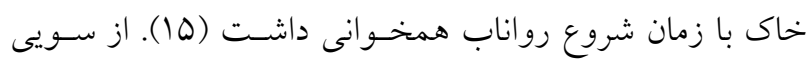

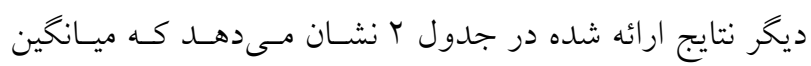

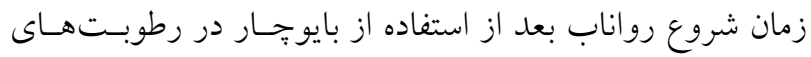

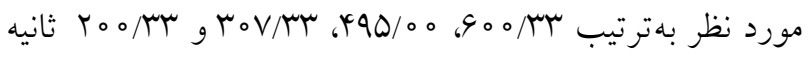
بود. نتايج نشان داد كه زمان شـروع روانـاب در تيمـار بايوجـار (با توجه به جدول \& و شكل \& (الف)) نسبت بـه تيمـار شـاهد

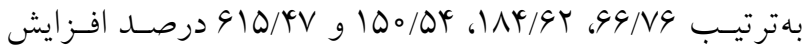
يافته است. نتايج جدول ه نيز نشان داد كه تأثير بايوجار بر زمان 
نتايج جدول ب نشان داد كه مقادير هدررفت خاك در تيمـار فاقـــ

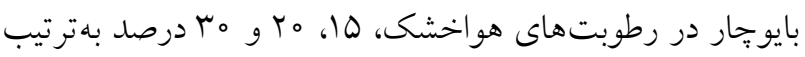
190/OT TAV/9A ه 1/90، 9ه/ نشان مىدهد كه بيشترين هدررفت خاك و غلظت رسوب مربوط به رطوبت هr درصد است كه اين نتايج با نتايج خالدى درويشان

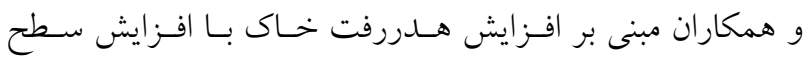

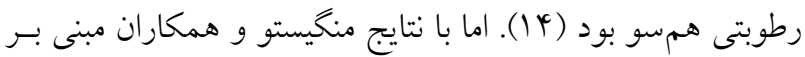

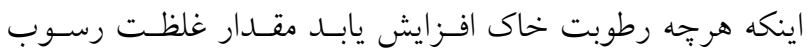

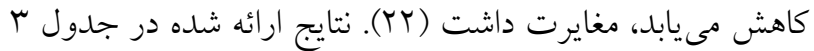
نشان مىدهــ كـه ميـانخين هــدررفـت خـاك بعـد از استفاده از

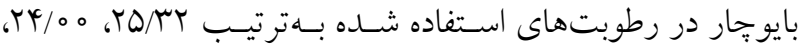

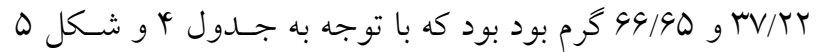

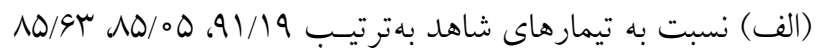

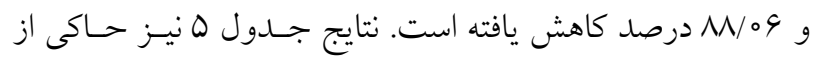
آن است كه تأثير بايوجار بر هدررفت خاك و غلظت رسوب بـ در

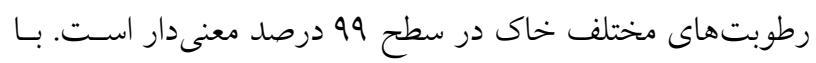

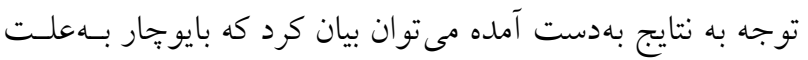

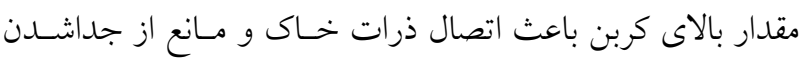

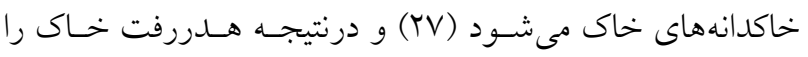

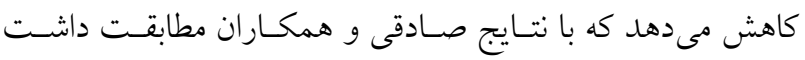

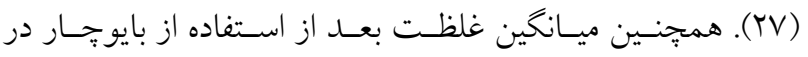

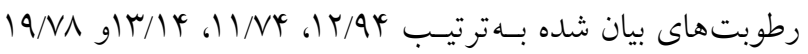

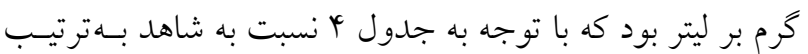

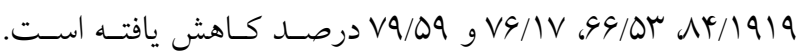
نتايج حاصل از كاهش در مقادير غلظـت رسـوب بعــ از كـاربرد بايوجـار بــا نتـايج صـادقى و همكـاران همخـوانى داشـت (YV).

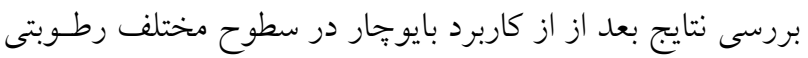
نشان داد كه اثر رطوبت خاك بر مؤلفههاى زمان شروع، حجـم و ضريب رواناب، هدررفت خاك و غلظـت رسـوب در سـطح 99 درصد معنى دار بود. تفكيكى و همخن بندى بـا استفاده از آزمـون دانكن در سطوح مختلف رطوبتى بعد از كاربرد بايوجـار نشـان
يافت كه نتايج حاصل با نتايج خالدى درويشان و همكاران مبنى بـر

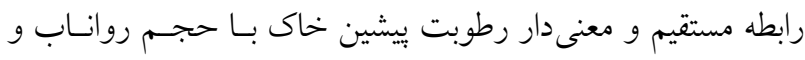

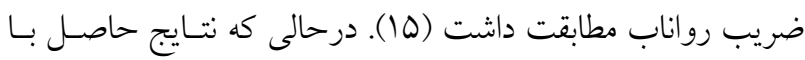

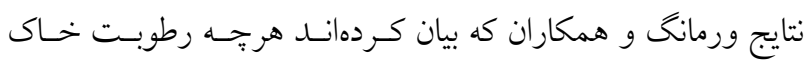

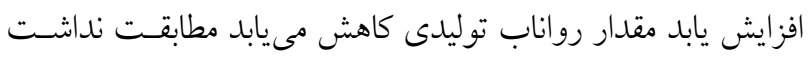

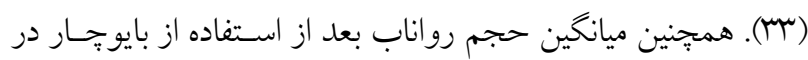
رطوبتهاى هواخشك، ها، مب و مب درصد خاك بهترتيـب 1/90،

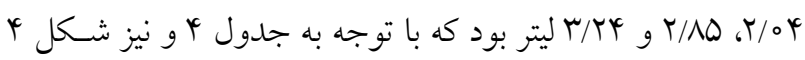

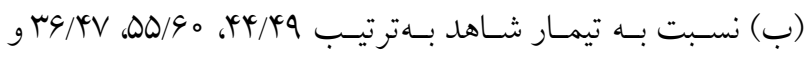

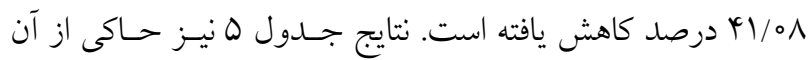

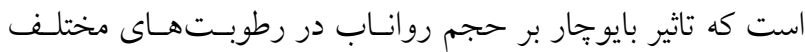

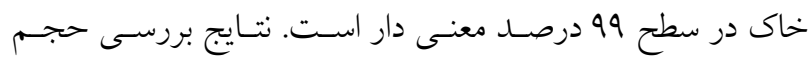

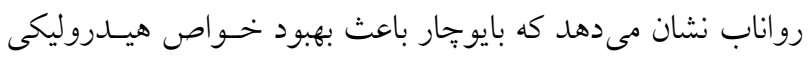
خاك شده (Yr)، همجنين كربن هاى فعـال آن باعـث اتصـال ذرات ريز خاك، افزايش تخلخل خاك و افزايش نفـوذ مسى أسود (TV) در نتيجه باعث كاهش حجم رواناب شده است. نتايج حاصل بـا نتسايج

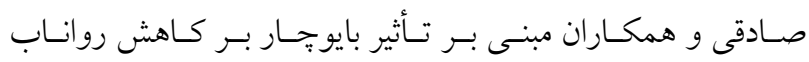

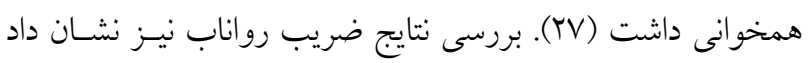

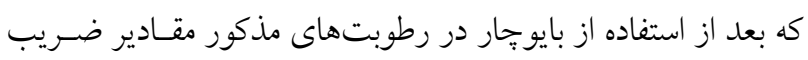

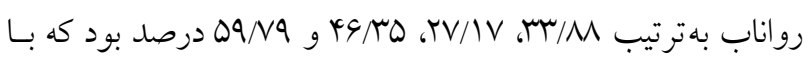

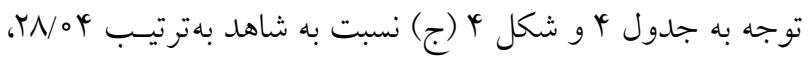

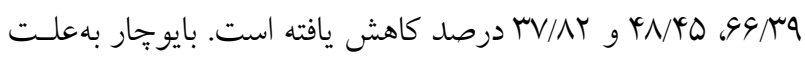

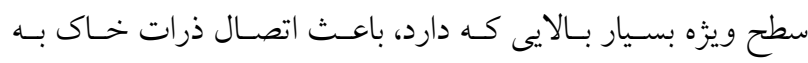

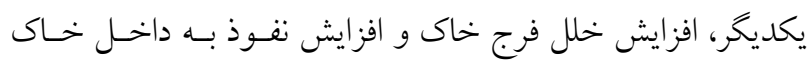

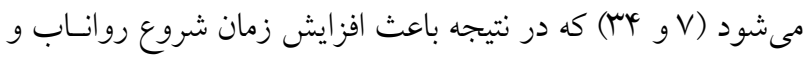

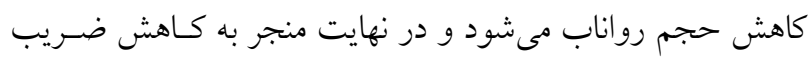

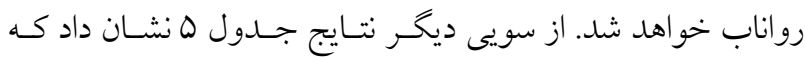

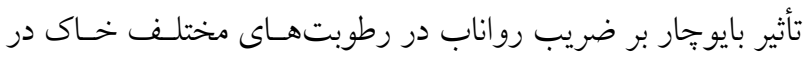

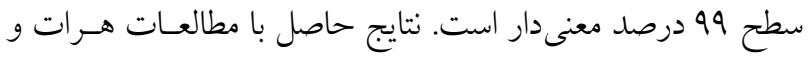

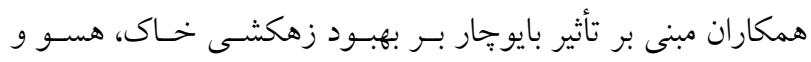

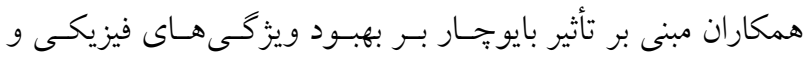
تخلخل خاك همخوانى داشت (10 و 11). 
ميزان هدررفت خاك نيز افزايش يافته است (Tr). اما دليل اينكه

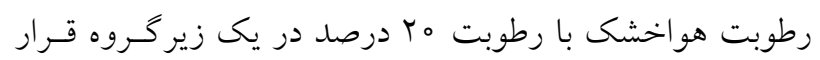

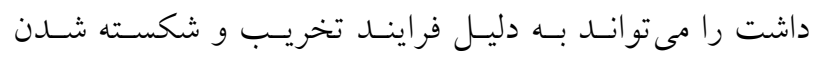

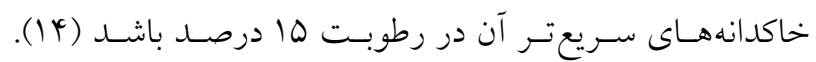

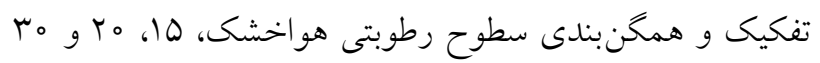

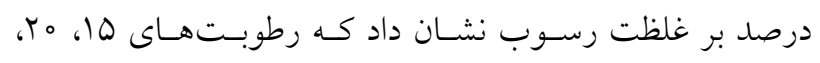

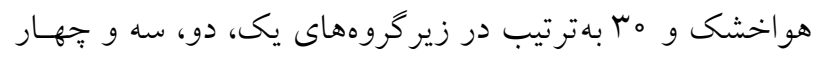

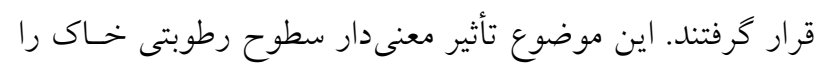

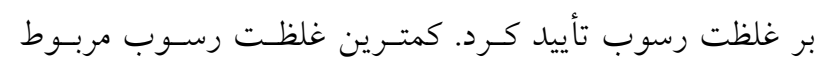

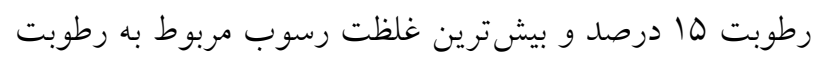

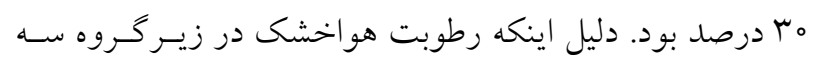

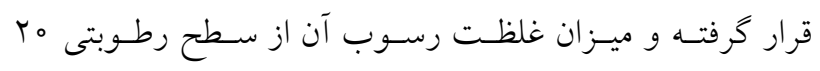

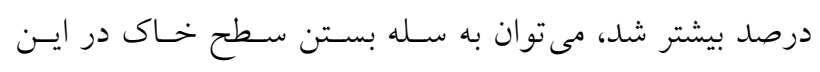

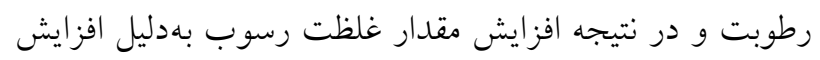

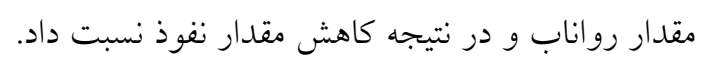

\section{نتيجه گيرى}

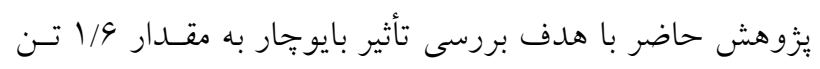

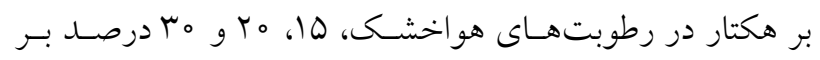

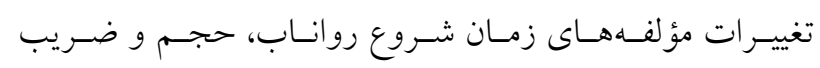

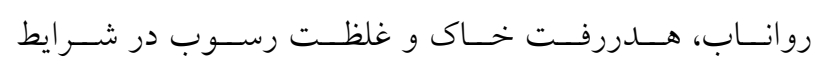
آزمايشخاهى و در مقياس كرتهاى آزمايشى انجام شد. امـروزه

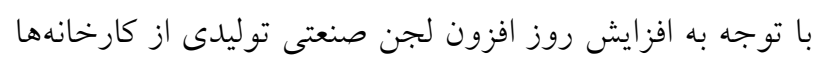

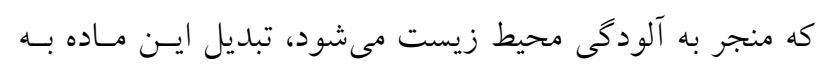

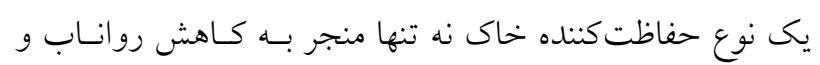

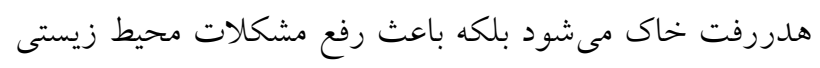

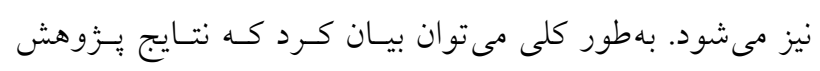

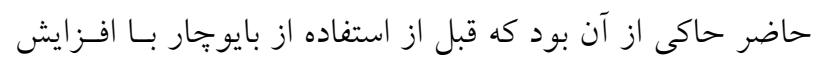

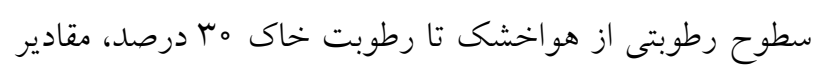

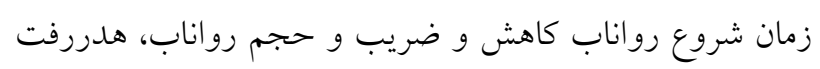

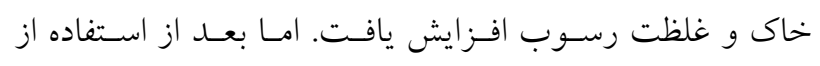

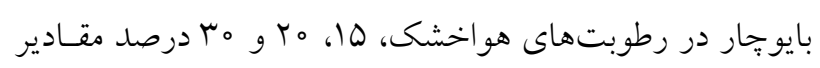

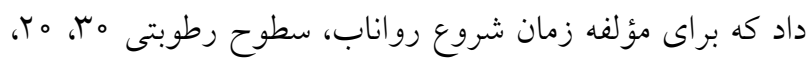

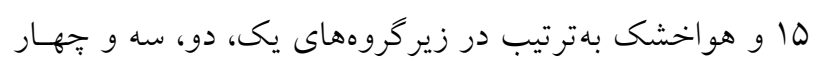

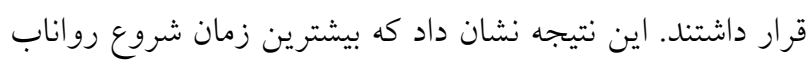

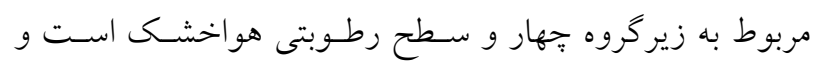

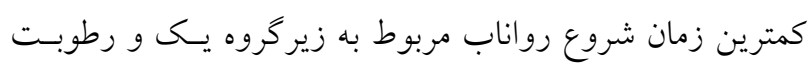

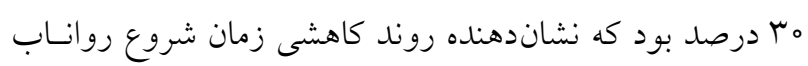

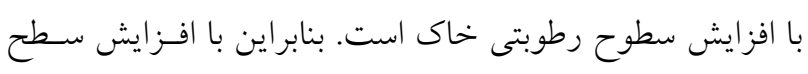
رطوبتى زمان شروع رواناب كاهش يافت. نتايج حاصل با نتسايج

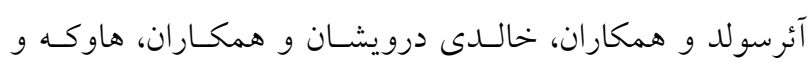

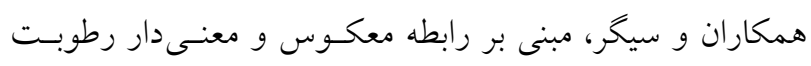

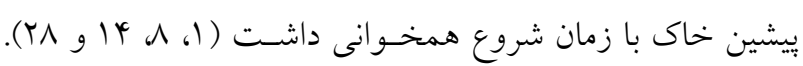

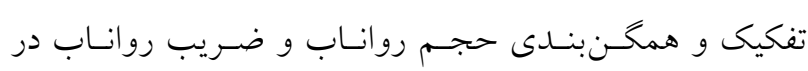

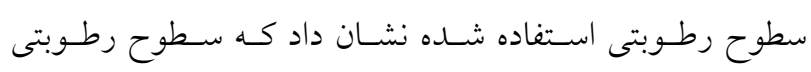

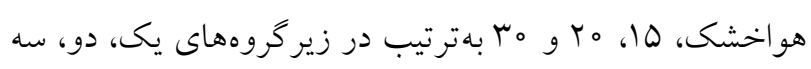

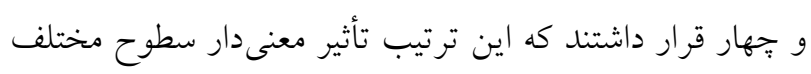

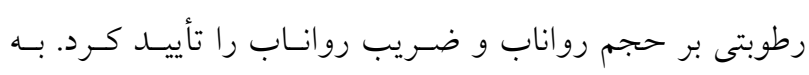

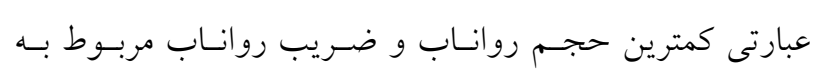

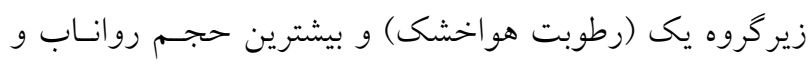

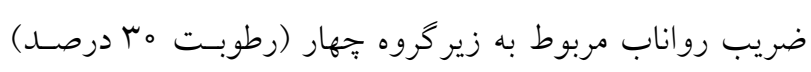

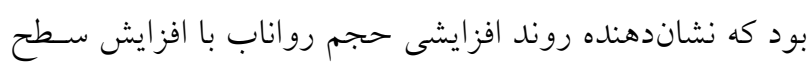

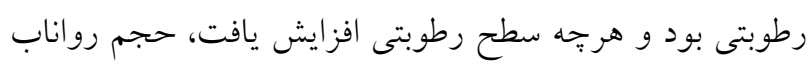

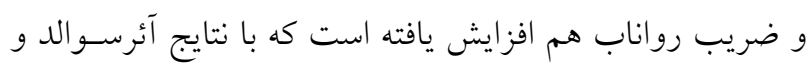

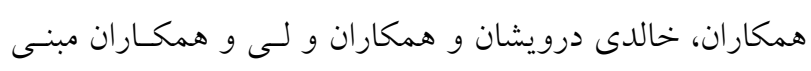

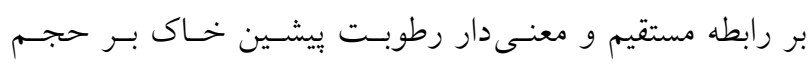

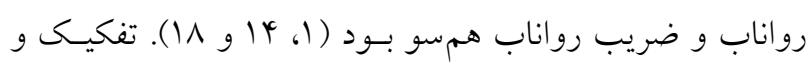

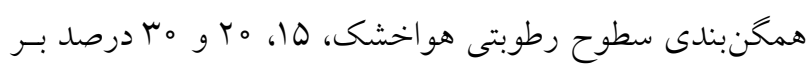

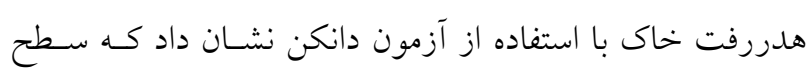

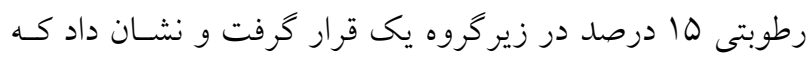

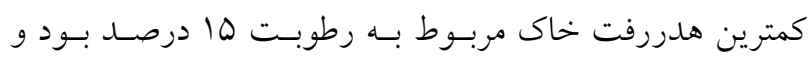

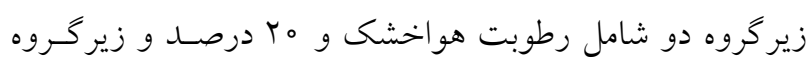

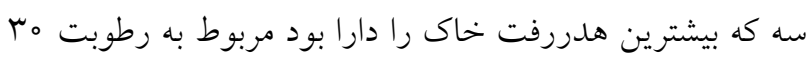

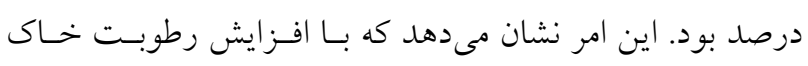




$$
\begin{aligned}
& \text { زمان شروع رواناب در مقايسـه بـا قبـل از اسـتفاده از بايوجــار كارخانه جوجهكشى علاوه بر كاهش آلايندههاى محيط زيستى، }
\end{aligned}
$$

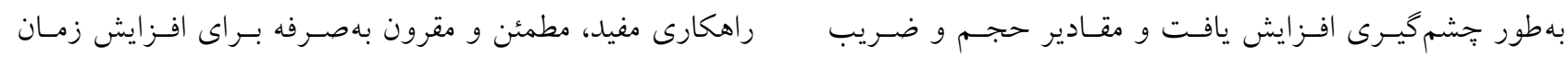

$$
\begin{aligned}
& \text { رواناب، هدررفت خاك و غلظت رسوب در مقايسـه بـا قبـل از شروع رواناب و كاهش حجم و ضريب رواناب، هدررفت خاى } \\
& \text { استفاده از بايو:حار در رطوبتهـاى مـذكور بـهــور معنسىدارى و غلظت رسوب است. } \\
& \text { كاهش يافت. بنـابراين اسـتفاده از بايوجــار تهيـهـ شــده از لجــن }
\end{aligned}
$$

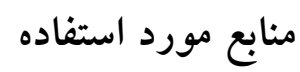

1. Auerswald, K. 1993. Influence of initial moisture and time since tillage on surface structure breakdown and erosion of a loessial soil. Catena 24: 93-101.

2. Baronti, S., F. P. Vaccari, F. Miglietta, C. Calzolari, E. Lugato, S. Orlandini, R. Pini, C. Zulian and L. Genesio. 2014. Impact of biochar application on plant water relations in Vitis vinifera (L.). European Journal of Agronomy 53: 38-44.

3. Briggs, C. M., J. Breiner, R. and C. Graham. 2005. Contributions of Pinus Ponderosa charcoal to soil chemical and physical properties. In: Proceeding of the ASACSSA-SSSA International Annual Meetings. Salt Lake City, USA.

4. Cammeraat, E. L. H. 2004. Scale dependent thresholds in hydrological and erosion response of a semi-arid catchment in southeast spain.agriculture. Ecosystems and Environment 104: 317-332.

5. Fliebach, A., R. Martens and H. H. Reber. 1994. Soil microbial biomass and microbial activity in soils treated with heavy metal contaminated sewage sludge. Soil Biologr and Biochemistry 26: 1201-1205.

6. Gholami, L., S. H. R. Sadeghi and M. Homaee. 2013. Straw mulching effect on splash erosion, runoff and sediment yield from eroded plots. Soil Science Society of America Journal 77: 268-278.

7. Githinji, L. 2013. Effect of biochar application rate on soil physical and hydraulic properties of a sandy loam. Archives of Agronomy and Soil Science 1-14.

8. Hawke, R. M., A. G. Price and R. B. Bryan. 2006. The effect of initial soil water content and rainfall intensity on near-surface soil hydrologic conductivity: a laboratory investigation. Catena 65: 237-246.

9. Haynes, R. J. and R. Naidu. 1998. Influence of lime, fertilizer and manure applications on soil organic matter content and soil physical conditions: a review. Nutrient Cycle in Agroecosystems 51: 123-137.

10. Herath, H. M. S. K., M. C. Arbestain and M. Hedley. 2013. Effect of biochar on soil physical properties in two contrasting soils: an alfisol and an andisol. Geoderma 209: 188-197.

11. Hseu, Z., Sh. Hao Jien, W.H. Chien and R. C. Liou. 2014. Impacts of biochar on physical properties and erosion potential of a mudstone slope land soil. The Scientific World Journal ID 602197, 10 p.

12. Husk, B. and J. Major 2010. Commercial scale agricultural biochar field trial in Québec, Canada over two years: effects of biochar on soil fertility, biology and crop productivity and quality. Dynamotive Energy Systems. Blue Leaf.

13. Jien, S. H. and C. S. Wang. 2013. Effects of biochar on soil properties and erosion potential in a highly weathered soil. Catena 110: 225-233.

14. Khaledi Darvishan A., S. H. R. Sadeghi, M. Homaee and M. Arabkhedri. 2014. Measuring sheet erosion using synthetic color-contrast aggregates. Hydrological Processes 28(15): 4463-4471.

15. Khaledi Darvishan, A., K. Banasik, S. H. R. Sadeghi, L. Gholami and L. Hejduk. 2015. Effects of rain intensity and initial soil moisture on hydrological responses in laboratory conditions. International Agrophysics 29: 165-173.

16. Laird, D. A., P. Fleming, D. D. Davis, R. Horton, B. Wang and D. L. Karlen 2010. Impact of biochar amendments on the quality of a typical Midwestern agricultural soil. Geoderma 158: 443-449.

17. Lehmann, J., M. C. Rillig, J. Thies, C. A. Masiello, W. C. Hockaday and D. Crowley. 2003. Biochar effects on soil biota- a review. Soil Biology Biochemstry 43: 1812-1836.

18. Li, J., F. Zhang, Sh. Wang and M. Yang. 2015. Combined influences of wheat-seedling cover and antecedent soil moisture on sheet erosion in small-flumes. Soil \& Tillage Research 151: 1-8.

19. Luk, S. H. 1985. Effect of antecedent soil moisture content on rainwash erosion. Catena 12: 129-139.

20. Luk, S. H. and H. Hamilton. 1986. Experimental effects of antecedent moisture and soil strength on rainwash erosion of two luvisols, ontario. Geoderma 37: 29-43.

21. Madejon, E., R. Lopez, J. M. Murillo and F. Cabrera. 2001. Agricultural use of three (sugar-beet) vinasse composts: effect on crops and chemical properties of a Cambisol soil in the Guadalquivir river valley (SW Spain). Agriculture \& Ecosystems Environment 84: 53-65.

22. Mengistu, B., M. Defersha and M. Melesse. 2012. Effect of rainfall intensity, slope and antecedent moisture content 
on sediment concentration and sediment enrichment ratio. Catena 90: 47-52.

23. Pappas, E. A., D. R.Smith, C. Huang, W. D. Shuster and J. V. Bonta. 2008. Impervious surface impacts to runoff and sediment discharge under laboratory rainfall simulation. Catena 72: 146-152.

24. Peter, P. Ch. 2018. Biochar and conservation agriculture nexus: synergy and research gaps for enhanced sustainable productivity in degraded soils-review. Communications in Soil Science and Plant Analysis 49(3): 389-403.

25. Petter, F. A. and B. E. Madari. 2012. Biochar: agronomic and environmental potential in Brazilian savannah soils. Revista Brasileira de Engenharia Agrícola e Ambiental 16 (7): 761-768.

26. Sachs, E. and P. Sarah. 2017. Combined effect of rain temperature and antecedent soil moisture on runoff and erosion on loess. Catena 158: 213-218.

27. Sadeghi, S. H. R., Z. Hazbavi and M. Kiani Harchegani. 2016. Controllability of runoff and soil loss from small plots treated by vinasse-produced biochar. Science of the Total Environment 541: 483-490.

28. Seeger, M. 2007. Uncertainty of factors determining runoff and erosion processes as quantified by rainfall simulations. Catena 71: 56-67.

29. Tejada, M. and J. L. Gonzalez. 2003. Effects of the application of a compost originating from crushed cotton gin residues on wheat yield under dryland conditions. European Journal Agronomy 19: 357- 368.

30. Trinsoutrot, J., B. Nicolardot, E. Justes and S. Recous. 2000. Decomposition in the field of residues of oilseed rape grown at two levels of nitrogen fertilization. Effects on the dynamics of soil mineral nitrogen between successive crops. Nutrient Cycle in Agroecosystems 56: 125-137.

31. Truman, C. C., T. L. Potter, R. C. Nuti, D. H. Franklin and D. D. Bosch. 2011. Antecedent water content effects on runoff and sediment yields from two Coastal Plain Ultisols. Agricultural Water Management 198: 1196-1189.

32. Uzoma, K. C., M. Inoue, H. Andry, A. Zahoor and E. Nishihara. 2011. Influence of biochar application on sandy soil hydraulic properties and nutrient retention. Food, Agriculture and Environment 9:1137-1143.

33. Vermang, J., V. Demeyer, W. M. Cornelis and D. Gabriels. 2009. Effect of antecedent soil-water content on aggregate stability and erodibility of a loess soil. Soil Science Society of America Journal 73: 718-726.

34. Zhang, F., Yang, M., Zhang, J. and Xie, Y. 2019. Impacts of biochar application rates and particle sizes on runoff and soil loss in small cultivated loess plots under simulated rainfall. Science of the Total Environment 1(649): 1403-1413. 


\title{
Protective Role of Biochar in Different Soil Moisture for Prevent Soil Loss in Laboratory Conditions
}

\author{
N. Karimi, L. Gholami* and A. Kavian ${ }^{1}$
}

(Received: February 27-2018; Accepted: November 17-2018)

\begin{abstract}
The using of soil conditioners to water and soil conservation is essential and also, the effect study of soil moisture on the soil conservation process and its role on changing runoff, soil erosion and sediment yield is necessary for understanding and simulating the hydrologic response of soil. Therefore, the present study was carried with the aim of investigating the effect of biochar with amount of $1.6 \mathrm{t}$ ha-1 on the components of time to runoff, runoff volume, runoff coefficient, soil loss and sediment concentration in different soil moisture including air-dried, 15, 20 and 30 percent with three replications in plot scale. The results showed that after application of biochar conditioner, time to runoff compared with control treatment at soil moistures of air-dried of 15, 20 and 30 percent happened later 66.66, 186.6, 150.5 , and 475.47 respectively. The results also showed that the runoff volume at soil moistures of air-dried of 15,20 and 30 percent decreased 44.49, 55.65, 36.47 and 41.08 percent, respectively, and the runoff coefficient reduced 55.71, $66.39,48.44$ and 37.82 percent, respectively. The adding biochar caused the decreasing soil loss with rates of 91.19 , $85.055,85.63$ and 88.066 percent, respectively, and the sediment concentration with amounts of $84.19,66.53,76.57$ and 79.59 percent, respectively. Also the results showed that the changes of soil moisture had the significant effect on changing the time to runoff, runoff volume, and soil loss and sediment concentration in level of 99 percent.
\end{abstract}

Keywords: Initial Soil Moisture, Laboratory Plot, Soil Erosion, Soil Organic Conditioner

1. Department of Watershed Management Engineering, Faculty of Natural Resources, Sari Agricultural Sciences and Natural Resources University, Sari, Iran.

*: Corresponding Author, Email: 1.gholami@sanru.ac.ir 